\title{
UPAYA MENINGKATKAN HASIL BELAJAR BIOLOGI MATERI GENETIK MELALUI MODEL PEMBELAJARAN STUDENT TEAM ACHIEVEMENT DIVISION DI KELAS XII MIPA 5 SMA NEGERI 19 PALEMBANG
}

\author{
Eni Asia \\ SMA Negeri 19 Palembang, Email: eni_a@gmail.com
}

\begin{abstract}
ABSTRAK
Tujuan penelitian ini adalah: Untuk mengetahui peningkatan hasil belajar Biologi materi Genetik setelah diterapkannya model pembelajaran Student Team Achievement Division (STAD) peserta didik kelas XII MIPA 5 SMA Negeri 19 Palembang. Dalam penelitian ini menggunakan bentuk guru sebagai peneliti, dimana guru sangat berpengaruh sekali dalam proses penelitian tindakan kelas. Dalam bentuk ini, tujuan utama penelitian kelas ialah untuk meningkatkan praktik-praktif pembelajaran di kelas. Dalam kegiatan ini, guru terlibat langsung secara penuh dalam proses perencanaan tindakan, observasi dan refleksi kehadiran pihak lain dalam penelitian ini peranannya tidak didominan dan sangat kecil. Penelitian ini bertempat di SMA Negeri 19 Palembang. Waktu penelitian adalah waktu berlangsungnya penelitian atau saat penelitian ini dilangsungkan. Penelitian ini dilaksanakan pada bulan September sampai dengan November tahun pelajaran 2018/2019. Subyek penelitian adalah siswa-siswi kelas XII MIPA 5 SMA Negeri 19 Palembangdengan jumlah 38 siswa, pada pokok bahasan menjelaskan materi genetik yaitu konsep gen, DNA, dan kromosom. Melalui hasil peneilitian ini menunjukkan bahwa pembelajaran dengan menggunakan model pembelajaran Student Team Achievement Division (STAD) memiliki dampak positif dalam meningkatkan hasil belajar biologi materi genetika yang mana didalamnya terdapat mengenai pembahasan mengenai Gen, Kromosom, dan DNA siswa kelas XII MIPA 5 SMA Negeri 19 Palembang. Hal ini dapat dilihat dari semakin mantapnya pemahaman dan penguasaan siswa terhadap materi yang telah disampaikan guru selama ini (ketuntasan belajar meningkat dari Pra Siklus (42,11\%), sklus I, (68,42\%), dan Siklus II $(92,11)$, Pada siklus II ketuntasan belajar siswa secara klasikal telah tercapai dan mengalami peningkatan yang sangat baik.
\end{abstract}

Kata Kunci: Biologi, Genetik, Student Teams Achievment Division.

\section{ABSTRACT}

The purpose of this study was to determine the increase in learning outcomes of Genetic Material Biology after the implementation of the Student Team Achievement Division (STAD) learning model of students of class XII MIPA 5 Palembang State High School 19. In this study using the form of a teacher as a researcher, where the teacher is very influential at 
all in the process of classroom action research. In this form, the main purpose of class research is to improve the practice of learning in the classroom. In this activity, the teacher is directly involved in the process of action planning, observation and reflection of the presence of other parties in this study whose role is not dominated and very small. The research took place at Palembang State High School 19. The time of research is the time the research takes place or when this research is held. This research was conducted from September to November of the 2018/2019 school year. The research subjects were students of class XII MIPA 5 Palembang State High School 19 with a total of 38 students, on the subject of explaining genetic material, namely the concept of genes, DNA, and chromosomes. Through this research, it shows that learning using the Student Team Achievement Division (STAD) learning model has a positive impact on improving the learning outcomes of biology genetic material which includes discussion of genes, chromosomes, and DNA in class XII MIPA 5 Palembang State High School 19. This can be seen from the more steady understanding and mastery of students on the material that has been delivered by the teacher so far (learning completeness increased from Pre Cycle (42.11\%), sklus I, (68.42\%), and Cycle II (92.11 ), In cycle II classical student mastery learning has been achieved and experienced a very good improvement.

Keywords: Biology, Genetics, Student Teams Achievement Division

\section{PENDAHULUAN}

Biologi didefinisikan sebagai kumpulan pengetahuan yang tersusun secara terbimbing. "Biologi berhubungan dengan cara mencari tahu tentang alam secara sistematis, sehingga bukan hanya penguasaan kumpulan pengetahuan yang berupa fakta, konsep, atau prinsipsaja tetapi juga merupakan suatu proses penemuan". Selain itu Biologi juga merupakan ilmu yang bersifat empirik dan membahas tentang fakta serta gejala alam. Fakta dan gejala alam tersebut menjadikan pembelajaran Biologi tidak hanya verbal tetapi juga faktual. Hal ini menunjukkan bahwa, hakikat Biologi sebagai proses diperlukan untuk menciptakan pembelajaran Biologi yang empirik dan faktual. Hakikat Biologi sebagai proses diwujudkan dengan melaksanakan pembelajaran yang melatih ketrampilan proses bagaimana cara produk sains ditemukan.

Bersdasarkan pengalaman penulis selama mengajar Biologi di SMA Negeri 19 Palembang, khususnya pada pada pokok pembelajaran menjelaskan konsep gen, dna, dan kromosom masih banyak nilai peserta 
didik yang rendah. Hal ini didapat dari hasil nilai pre test yang diberikan guru telebih dahulu sebelum melanjutkan materi pembelajaran.

Dari hasil yang diperoleh terlihat bahwa masih banyak peserta didik belum atau tidak paham pelajaran. Hal ini pun terlihat dari hasil nilai ulangan harian materi sebelumnya yang telah dilaksakan pada 3 September 2018 yang belum mencapai kriteria ketuntasan minimum (KKM). Data menunjukkan bahwa sebanyak $42.11 \%$ atau 16 peserta didik yang mendapatkan nilai $\geq 75$, sedangkan sisanya $57.89 \%$ atau sebanyak 22 peserta didik lainnya mendapatkan nilai <75. Itu artinya lebih dari 50\% dari jumlah peserta didik belum mencapai KKM. Sedangkan untuk mencapai standart KKM peserta didik harus mendapatkan nilai $\geq 75$.

Untuk itu saya sebagai guru biologi tidak akan lepas dari tanggungjawab agar meningkatnya hasil belajar peserta didik. Oleh karena itu saya bermaksud mengkaji ulang pembelajaran untuk mengatasi permasalahan tersebut untuk membuat peserta didik lebih memahami dan mengerti pada materi yang diajarkan khusunya pada materi gen, DNA dan Kromosom.
Penulis mencoba menerapkan model pembelajaran Student Team Achievement Division (STAD). Student Team Achievement Division termasuk dalam model pembelajaran kooperatif yang dapat meningkatkan rasa percaya diri dan keaktifan siswa dalam belajar hal ini dikarenakan setiap kelompok terdiri dari empat atau lima orang sehingga setiap siswa akan mendapatkan kesempatan untuk berpartisipasi dalam kelas. Menurut Slavin, dalam (Isjoni 2009:51), kooperatif tipe STAD di kembangkannya sebagai salah satu tipe kooperatif yang menekankan pada aktivitas dan interaksi diantara siswa untuk saling membantun dalam menguasai materi pelajaran guna mencapai hasil maksimal.Oleh karena itu model pembelajaran yang digunakan haruslah sesuai dan tepat agar dapat memotivasi siswa untuk belajar sehingga kemampuan pengetahuannya mengenai materi genetik.

Berdasarkan uraian di atas, maka yang menjadi rumusan masalah dalam penelitian ini yaitu: Bagaimanakah peningkatan hasil belajar Biologi materi Genetik setelah diterapkannya model pembelajaran Student Team Achievement Division (STAD) peserta 
didik kelas XII MIPA 5 SMA Negeri

19 Palembang?

Sesuai dengan rumusan masalah yang telah dikemukakan di atas, maka yang menjadi tujuan penelitian ini adalah: Untuk mengetahui peningkatan hasil belajar Biologi materi Genetik setelah diterapkannya model pembelajaran Student Team Achievement Division (STAD) peserta didik kelas XII MIPA 5 SMA Negeri 19 Palembang.

Biologi merupakan mata pelajaran yang termasuk dalam rumpun ilmu pengetahuan alam (IPA atau sains). Ilmu sains berkaitan dengan cara mencari tahu (inquiry) tentang alam secara sistematis, sehingga pembelajaran bukan hanya sebagai penguasaan kumpulan pengetahuan yang berupa fakta-fakta, konsep-konsep atau prinsip-prinsip saja, tetapi juga merupakan suatu proses penemuan. Pembelajaran biologi di sekolah menengah diharapkan dapat menjadi wahana bagi peserta didik untuk mempelajari diri sendiri dan alam sekitar, serta prospek pengembangan lebih lanjut dalam kehidupan seharihari.

Sehubungan dengan itu, pembelajaran biologi menekankan pada pemberian pengalaman langsung untuk mengembangkan kompetensi agar peserta didik menjelajahi dan memahami alam sekitar secara ilmiah. Pembelajaran biologi diarahkan untuk mencari tahu dan berbuat sehingga dapat membantu peserta didik untuk memperoleh pemahaman yang lebih mendalam tentang dirinya sendiri dan alam sekitar.

Standar kompetensi dalam kurikulum pembelajaran biologi menyediakan berbagai pengalaman belajar untuk memahami konsep dan proses sains. Keterampilan proses ini meliputi keterampilan mengamati, mengajukan hipotesis, menggunakan alat dan bahan secara baik dan benar dengan selalu mempertimbangkan keamanan dan keselamatan kerja, mengajukan pertanyaan, menggolongkan dan menafsirkan data, serta mengkomunikasikan hasil temuan secara lisan atau tertulis, menggali dan memilah informasi faktual yang relevan untuk menguji gagasan-gagasan atau memecahkan masalah sehari-hari.

Mata pelajaran biologi dikembangkan melalui kemampuan berpikir analitis, induktif, dan deduktif untuk menyelesaikan masalah yang berkaitan dengan peristiwa alam 
sekitar. Penyelesaian masalah yang bersifat kualitatif dan kuantitatif dilakukan dengan menggunakan pemahaman dalam bidang matematika, fisika, kimia, dan pengetahuan pendukung lainnya.

https://mahmuddin.wordpress.com/2013 /06/10/hakikat-pembelajaran-biologi-disekolah/ diakses 10 September 2018

Setiap proses belajar mengajar yang dilakukan oleh SMA Negeri 19 Palembang dapat menghasilkan hasil belajar. Hasil belajar yang baik hanya dapat dicapai melalui proses yang bermutu, jika proses belajar mengajar tidak optimal sangat sulit dihasilkan hasil belajar yang baik. Menurut Sudjana (2005:22) "hasil belajar adalah kemampuan yang dimiliki SMA Negeri 19 Palembang setelah ia menerima pengalaman belajar". Hasil belajar biologi yaitu hasil belajar yang diperoleh dalam belajar biologi untuk mengukur keberhasilan seseorang dalam memahami pelajaran dapat menggunakan tes yang disajikan dalam bentuk angka atau nilai tertentu. Nilai yang diperoleh dalam penelitian ini adalah hasil belajar yang diperoleh setelah proses belajar-mengajar berlangsung.

$$
\text { Kunandar }
$$

memaparkan bahwa hasil belajar adalah kompetensi atau kemampuan tertentu baik kognitif, afektif maupun psikomotorik yang dicapai atau dikuasai peserta didik setelah mengikuti proses belajar mengajar. Selain itu, pendapat lain menjelaskan bahwa hasil belajar merupakan prestasi belajar peserta didik secara keseluruhan yang menjadi indikator kompetensi dasar dan derajat perubahan prilaku yang bersangkutan (Mulyasa, 2009:212). Berdasarkan beberapa pendapat di atas, dapat kita simpulkan bahwa hasil belajar merupakan kompetensi atau kemampuan peserta didik menguasai suatu kompetensi dasar, baik ranah kognitif, afektif, maupun psikomotorik setelah mengikuti kegiatan atau proses belajar mengajar.

Model pembelajaran adalah suatu perencanaan atau suatu pola yang digunakan sebagai pedoman dalam merencanakan pembelajaran di kelas atau pembelajaran dalam tutorial dan untuk menentukan perangkat-perangkat pembelajaran termasuk didalamnya buku-buku, film, komputer, kurikulum dan lain-lain. Pembelajaran kooperatif adalah suatu strategi pembelajaran yang menekankan pada sikap atau perilaku bersama dalam bekerja atau membantu di antara sesama dalam struktur kerja 
sama yag teratur pada kelompok yang terdiri atas dua orang atau lebih (Tampobolon, 2014:89). Selanjutnya Huda (2014:29) menjelaskan bahwa pembelajaran kooperatif merupakan aktivitas pembelajaran kelompok yang diorganisir oleh suatu prinsip bahwa perubahan informasi secara sosial di antara kelompok-kelompok pembelajar yang di dalamnya setiap pembelajar bertanggung jawab atas pembelajaran sendiri dan didorong untuk meningkatkan pembelajaran anggotaanggota yang lain.

Senada dengan kedua pendapat tersebut, Isjoni (2009: 17) mengatakan bahwa pengertian model pembelajaran kooperatif yaitu mengelompokkan siswa di dalam kelas ke dalam suatu kelompok kecil agar siswa dapat bekerja sama dengan kemampuan maksimal yang mereka miliki dan mempelajari satu sama lain dalam kelompok. Dari ketiga pendapat di atas dapat disimpulkan bahwa pembelajaran kooperatif adalah suatu strategi pembelajaran dengan mengelompokkan peserta didik ke dalam beberapa kelompok yang terdiri dari dua orang atau lebih yang menekankan pada sikap atau perilaku dalam bekerja sama dalam memecahkan masalah atau mempelajari sesuatu untuk meningkatkan pengetahuan individu dan anggotaanggota kelompok yang lain.

Model pembelajaran kooperatif tipe Student Teams Achievement Division (STAD) adalah pembelajaran yang mengelompokkan kemampuan campuran yang melibatkan pengakuan tim dan tanggung jawab kelompok pembelajaran individu anggota (keanggotaan campuran menurut tingkat prestasi, jenis kelamin, suku). (Suyatno, 2009:52). Menurut Slavin, dalam (Isjoni 2009:51), kooperatif tipe STAD di kembangkannya sebagai salah satu tipe kooperatif yang menekankan pada aktivitas dan interaksi diantara siswa untuk saling membantun dalam menguasai materi pelajaran guna mencapai hasil maksimal.

Pada proses pembelajarannya, belajar kooperatif tipe Student Teams Achievement Division (STAD) dengan langkah-langkah menurut (suprijono, 2009: 133) adalah sebagai berikut:

a. Membentuk kelompok yang anggotanya $=4$ atau 5 orang secara heterogen (campuran menurut prestasi, jenis kelamin, suku dan lain-lain).

b. Guru menyajikan pelajaran. 
c. Guru memberikan tugas kepada kelompok untuk di kerjakan oleh anggota-anggota kelompok, anggota yang belum mengerti menjelaskan kepada anggota lainnya sampai semua anggota dalam kelompok itu mengerti.

d. Pemberian penghargaan

e. Guru memberi kuis/pertanyaan kepada seluruhsiswa.

f. Memberi evaluasi

g. Kesimpulan.

\section{METODE}

Penelitian ini merupakan penelitian tidnakan (action research), karena penelitian dilakukan untuk memecahkan masalah pembelajaran di kelas. Penelitian ini juga termasuk penelitian dskriptif, sebab menggambarkan bagaimana suatu teknik pembelajaran diterapkan dan bagaimana hasil yang diinginkan dapat dicapai. Menurut Sukidin dkk (2002:54) ada 4 macam bentuk penelitian tindakan, yaitu: (1) penelitian tindakan guru sebagai peneliti, (2) penelitian tindakan kolaborasi, (3) penelitian tindakan simultan terintegratif dan (4) penelitian tindakan social eksperimental.
Keempat bentuk penelitian tindakan di atas, ada persamaan dan pembedaannya. Menurut Oja dan Smulyan sebagaimana dikutip oleh Kasbilah (dalam Sukidin, dkk. 2002:55), ciri-ciri dari setiap penelitian tergantung pada (1) tujuan utamanya atau pada tekanannya, (2) tingkat kolaborasi antara pelaku penelitian dan peneliti dari luar, (3) proses yang digunakan dalam melakukan penelitian dan (4) hubungan antara proyek dengan sekolah.

Dalam penelitian ini menggunakan bentuk guru sebagai peneliti, dimana guru sangat berpengaruh sekali dalam proses penelitian tindakan kelas. Dalam bentuk ini, tujuan utama penelitian kelas ialah untuk meningkatkan praktik-praktif pembelajaran di kelas. Dalam kegiatan ini, guru terlibat langsung secara penuh dalam proses perencanaan tindakan, observasi dan refleksi kehadiran pihak lain dalam penelitian ini peranannya tidak didominan dan sangat kecil. Waktu penelitian adalah waktu berlangsungnya penelitian atau saat penelitian ini dilangsungkan. Penelitian ini dilaksanakan pada bulan September sampai dengan November tahun pelajaran 2018/2019. Subyek penelitian 
adalah siswa-siswi kelas XII MIPA 5

SMA Negeri 19 Palembangdengan jumlah 38 siswa, pada pokok bahasan menjelaskan materi genetik yaitu konsep gen, DNA, dan kromosom.

\section{PEMBAHASAN}

Siklus I

Pada akhir proses belajar mengajar peserta didik diberi post test I dengan tujuan untuk mengetahui tingkat keberhasilan peserta didik dalam proses belajar mengajar yang telah dilakukan. Adapun data hasil penelitian pada siklus I adalah sebagai berikut:

Tabel 1. Tabel Observasi Pembelajaran Pada Siklus I

\begin{tabular}{|c|c|c|c|}
\hline \multirow{2}{*}{ No } & \multirow{2}{*}{$\begin{array}{c}\text { Aktivitas } \\
\text { Belajar Siswa }\end{array}$} & \multicolumn{2}{|c|}{ Banyak Siswa } \\
\hline & & $\begin{array}{c}\text { Pertemuan } \\
1\end{array}$ & $\begin{array}{c}\text { Pertemuan } \\
2 \\
\end{array}$ \\
\hline 1 & $\begin{array}{l}\text { Antusias } \\
\text { Dalam } \\
\text { Persentasi }\end{array}$ & $\begin{array}{l}27 \text { anak } \\
71,05 \%\end{array}$ & $\begin{array}{l}30 \text { anak } \\
78,95 \%\end{array}$ \\
\hline 2 & Aktif Bertanya & $\begin{array}{l}15 \text { anak } \\
39,47 \%\end{array}$ & $\begin{array}{l}23 \text { anak } \\
60,53 \%\end{array}$ \\
\hline 3 & $\begin{array}{l}\text { Aktif } \\
\text { Menjawab } \\
\text { Pertanyaan }\end{array}$ & $\begin{array}{l}16 \text { anak } \\
42,11 \%\end{array}$ & $\begin{array}{l}23 \text { anak } \\
60,53 \%\end{array}$ \\
\hline \multirow{2}{*}{$\cdot$} & \multirow{2}{*}{ Aktivitas Guru } & \multicolumn{2}{|c|}{ Kualitas } \\
\hline & & $\begin{array}{c}\text { Pertemuan } \\
1\end{array}$ & $\begin{array}{l}\text { Pertemuan } \\
2\end{array}$ \\
\hline 1 & $\begin{array}{l}\text { Memberikan } \\
\text { Umpan Balik }\end{array}$ & kurang & Cukup \\
\hline 2 & $\begin{array}{l}\text { Menyimpulkan } \\
\text { Materi } \\
\text { Pembelajaran }\end{array}$ & cukup & Cukup \\
\hline
\end{tabular}

\begin{tabular}{llll}
\hline & $\begin{array}{l}\text { Melakukan } \\
\text { refleksi dari } \\
\text { setiap kegiatan } \\
\text { pembelajaran } \\
\text { yang telah } \\
\text { dilakukan }\end{array}$ & cukup & Baik \\
\hline & $\begin{array}{l}\text { Melakukan } \\
\text { penilaian } \\
\text { secara objektif }\end{array}$ & baik & $\begin{array}{c}\text { Sangat } \\
\text { baik }\end{array}$ \\
\hline
\end{tabular}

Hasil jumlah skor di atas merupakan pengamatan yang dilakukan teman sejawat bernama Ibu Resmi Rosmawati, S.Pd. yang bertugas sebagai kolaborator mengawasi jalannya penelitian yang dilakukan guru di kelas. Pada aktivitas guru memberikan umpan balikpada pertemuan 1 mendapat penilaian kurang dari pengamat, pada pertemuan ke 2 nilai 3, aktivitas menyimpulkan materi pembelajaran pertemuan 1 dan 2 mendapat nilai 3 atau cukup, melakukan refleksi dari setiap kegiatan pembelajaran yang telah dilakukan cukup dan baik di pertemuan 1 dan 2, melakukan penilaian secara objektif pertemuan 1 baik dan pertemuan 2 sangat baik. Penilaian tersebut di atas dirasakan sudah baik namun masih ada kekurangan yang akan diperbaiki di siklus II.

Tabel 2. Hasil Ketuntasan Belajar Biologi

No. Uraian $\begin{gathered}\text { Jumah } \\ \text { Siswa }\end{gathered}$




\begin{tabular}{llcc}
\hline 1. & $\begin{array}{l}\text { Siswa } \\
\text { Tuntas }\end{array}$ & 26 & 68,42 \\
\hline 2. & $\begin{array}{l}\text { Belum } \\
\text { Tuntas }\end{array}$ & 12 & 13,26 \\
\hline
\end{tabular}

Dari table di atas dapat dijelaskan bahwa dengan menerapkan pembelajaran dengan menggunakan model pembelajaran Student Team Achievement Division (STAD) diperoleh ketuntasan belajar mencapai $68,42 \%$ atau baru ada 26 peserta didik dari 38 peserta didik yang telah tuntas belajar, sedangkan 12 orang belum tuntas belajar. Hasil tersebut menunjukkan bahwa pada siklus pertama peserta didik belum tuntas belajar, karena peserta didik yang memperoleh nilai $\geq 75$ hanya sebesar $68,42 \%$ lebih kecil dari persentase ketuntasan yang dikehendaki yaitu sebesar $85 \%$.

\section{Siklus II}

Pada akhir proses belajar mengajar peserta didik diberi post test II dengan tujuan untuk mengetahui tingkat keberhasilan peserta didik dalam proses belajar mengajar yang telah dilakukan. Instrumen yang digunakan adalah post test II. Adapun data hasil penelitian pada siklus II adalah sebagai berikut.

Tabel 3 Tabel Observasi Pembelajaran Pada Siklus II

\begin{tabular}{|c|c|c|c|}
\hline \multirow[b]{2}{*}{ No } & \multirow{2}{*}{$\begin{array}{l}\text { Aktivitas } \\
\text { Belajar Siswa }\end{array}$} & \multicolumn{2}{|c|}{ Banyak Siswa } \\
\hline & & $\begin{array}{l}\text { Pertemuan } \\
1\end{array}$ & Pertemuan 2 \\
\hline \multirow{2}{*}{1} & Antusias Dalam & 32 anak & 38 anak \\
\hline & Persentasi & $84,21 \%$ & $100 \%$ \\
\hline \multirow{2}{*}{2} & \multirow{2}{*}{ Aktif Bertanya } & 20 anak & 30 anak \\
\hline & & $52,63 \%$ & $78,95 \%$ \\
\hline \multirow{2}{*}{3} & Aktif Menjawab & 32 anak & 35 anak \\
\hline & Pertanyaan & $84,21 \%$ & $92,11 \%$ \\
\hline \multirow{2}{*}{ No. } & \multirow{2}{*}{ Aktivitas Guru } & \multicolumn{2}{|l|}{ Kualitas } \\
\hline & & $\begin{array}{l}\text { Pertemuan } \\
1\end{array}$ & $\begin{array}{l}\text { Pertemuan } \\
2\end{array}$ \\
\hline 1 & $\begin{array}{l}\text { Memberikan } \\
\text { Umpan Balik }\end{array}$ & baik & $\begin{array}{l}\text { Sangat } \\
\text { baik }\end{array}$ \\
\hline 2 & $\begin{array}{l}\text { Menyimpulkan } \\
\text { Materi } \\
\text { Pembelajaran }\end{array}$ & baik & $\begin{array}{l}\text { Sangat } \\
\text { baik }\end{array}$ \\
\hline 3 & $\begin{array}{l}\text { Melakukan } \\
\text { refleksi dari } \\
\text { setiap kegiatan } \\
\text { pembelajaran } \\
\text { yang telah } \\
\text { dilakukan } \\
\end{array}$ & baik & $\begin{array}{l}\text { Sangat } \\
\text { Baik }\end{array}$ \\
\hline 4 & $\begin{array}{l}\text { Melakukan } \\
\text { penilaian secara } \\
\text { objektif }\end{array}$ & baik & $\begin{array}{l}\text { Sangat } \\
\text { baik }\end{array}$ \\
\hline
\end{tabular}

Dari tabel diatas, Hasil jumlah skor di atas merupakan pengamatan siklus ke dua yang dilakukan teman sejawat. Pada aktivitas guru memberikan umpan balik pada pertemuan 1 mendapat penilaian 'baik' dari pengamat, pada pertemuan ke 2 nilai 5 atau sangat baik, aktivitas menyimpulkan materi pembelajaran pertemuan 1 dan 2 mendapat nilai 4 dan 5 kategori baik dan sangat baik, melakukan refleksi dari setiap kegiatan pembelajaran yang telah dilakukan baik dan sangat baik di pertemuan 1 dan 2, melakukan penilaian secara objektif pertemuan 1 baik 
dan pertemuan 2 sangat baik. Aspek-aspek pengamatan yang dilakukan guru bersama teman sejawat yang mendapatkan penilaian sudah baik, dan tidak akan dilanjutkan lagi ke siklus selanjutnya.

Tabel 4. Hasil Ketuntasan Belajar Biologi Siklus II

\begin{tabular}{clcc}
\hline No. & Uraian & $\begin{array}{c}\text { Jumah } \\
\text { Siswa }\end{array}$ & Persentase \\
\hline 1. & Siswa Tuntas & 35 & 92,11 \\
\hline 2. & $\begin{array}{l}\text { Belum } \\
\text { Tuntas }\end{array}$ & 3 & 7,89 \\
\hline
\end{tabular}

Berdasarkan table di atas diperoleh dari 38 peserta didik yang telah tuntas sebanyak 35 peserta didik dan 3 peserta didik belum mencapai ketuntasan belajar. Maka secara klasikal ketuntasan belajar yang telah tercapai sebesar $92.11 \%$ (termasuk kategori tuntas). Hasil pada siklus II ini mengalami peningkatan lebih baik dari siklus I. Adanya peningkatan hasil belajar pada siklus II ini dipengaruhi oleh adanya peningkatan kemampuan peserta didik dalam mempelajari materi pelajaran yang telah diterapkan selama ini. Hal ini dipengaruhi oleh kemampuan guru dalam mengelola proses belajar mengajar selama kegiatan pembelajaran yang berlangsung.

\section{Pembahasan}

Hasil peneilitian ini menunjukkan bahwa pembelajaran dengan menggunakan model pembelajaran Student Team Achievement Division (STAD) memiliki dampak positif dalam meningkatkan hasil belajar biologi materi genetik melalui model pembelajaran Student Team Achievement Division (STAD) Peserta didik Kelas XII MIPA 5 SMA Negeri 19 Palembang. Hal ini dapat dilihat dari semakin mantapnya pemahaman dan penguasaan peserta didik terhadap materi yang telah disampaikan guru selama ini dari sebelum penggunaan model, siklus I dan Siklus II dengan hasil dibawah ini:

Tabel 5. Hasil Ketuntasan Belajar Biologi Tiap Siklus

\begin{tabular}{clcc}
\hline No. & Uraian & $\begin{array}{c}\text { Jumah } \\
\text { Siswa }\end{array}$ & Persentase \\
\hline 1. & Pra Siklus & 16 & 42,11 \\
\hline 2. & Siklus I & 26 & 68,42 \\
\hline 3 & Siklus II & 35 & 92,11 \\
\hline
\end{tabular}

\section{PENUTUP}

\section{Kesimpulan}

Melalui hasil peneilitian ini menunjukkan bahwa pembelajaran dengan menggunakan model pembelajaran Student Team Achievement Division (STAD) memiliki dampak positif dalam meningkatkan 
hasil belajar biologi materi genetika yang mana didalamnya terdapat mengenai pembahasan mengenai Gen, Kromosom, dan DNA siswa kelas XII MIPA 5 SMA Negeri 19 Palembang. Hal ini dapat dilihat dari semakin mantapnya pemahaman dan penguasaan siswa terhadap materi yang telah disampaikan guru selama ini (ketuntasan belajar meningkat dari Pra Siklus (42,11\%), sklus I, $(68,42 \%)$, dan Siklus II $(92,11), \quad$ Pada siklus II ketuntasan belajar siswa secara klasikal telah tercapai dan mengalami peningkatan yang sangat baik.

\section{Saran}

Karena hasil penelitian setelah diterapkan model pembelajaran Student Team Achievement Division (STAD) pada mata pelajaran Biologi menunjukkan siswa melakukan aktifitas berdasarkan indikator dan hasil belajar siswa dalam kategori baik, maka peneliti menyarankan kapada guru hendaknya menerapkan model pembelajaran Student Team Achievement Division (STAD) yang dapat dijadikan alternatif dalam semua pembelajaran khususnya Biologi.

\section{DAFTAR PUSTAKA}

Agus Suprijono. 2009. Cooperative Learning: Teori dan Aplikasi PAIKEM. Yogyakarta : Pustaka Pelajar

https://mahmuddin.wordpress.com/2013 /06/10/hakikat-pembelajaranbiologi-di-sekolah/ diakses 10 September 2018

Isjoni. (2009). Cooperative Learning: Mengembangkan Kemampuan Belajar Kelompok.Bandung: Alfabeta.

Kunandar. (2013). Penilaian Autentik. Raja Grafindo Persada. Jakarta. Mulyasa.(2009). Praktik Penelitian Tindakan Kelas. Bandung. Rosda Karya.

Sudikin, dkk. (2002). "Manajemen Penrlitian Tindakan Kelas”. Insan Cendekia.

Sudjana. (2005). Strategi Pembelajaran. Bandung: Falah Production. Suyatno.2009. Menjelajah Pembelajaran Inofatif.(Sidoarjo:Masmedia Buana Pusaka)

Sugiyono. (2013). Metode Penelitian Pendidikan Pendekatan Kuantitatif,. Kualitatif, dan R\&D. Bandung: Alfabeta. 
Tampubolon, Saur. (2014). Penelitian

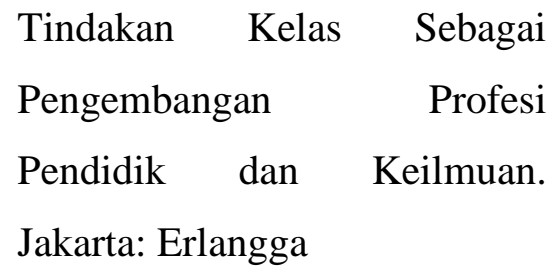

